\title{
Evaluation of morpho-anatomical and chemical differences between varieties of the medicinal plant Casearia sylvestris Swartz
}

\author{
JOSIANE C. CLAUDINO ${ }^{1}$, LUIS V.S. DO SACRAMENTO ${ }^{2}$, INGRID KOCH ${ }^{3}$, HELEN A. SANTOS ${ }^{3}$, \\ ALBERTO J. CAVALHEIRO ${ }^{4}$, ARISTEU G. TININIS ${ }^{5}$ and ANDRÉ G. DOS SANTOS ${ }^{1}$ \\ ${ }^{1}$ Laboratório de Farmacognosia/LAPDESF, Faculdade de Ciências Farmacêuticas, Universidade Estadual Paulista/UNESP, \\ Rodovia Araraquara-Jaú, Km 01, Bairro Campus, 14801-902 Araraquara, SP, Brasil \\ ${ }^{2}$ Laboratório de Farmacobotânica, Faculdade de Ciências Farmacêuticas, \\ Universidade Estadual Paulista/UNESP, 14801-902 Araraquara, SP, Brasil \\ ${ }^{3}$ Curso de Biologia, Universidade Federal de São Carlos/UFSCar, Campus Sorocaba, \\ Rodovia João Leme dos Santos, Km 110, Bairro do Itinga, 18052-780 Sorocaba, SP, Brasil \\ ${ }^{4}$ Núcleo de Bioensaios Biossíntese e Ecofisiologia de Produtos Naturais, \\ Instituto de Química, UNESP, 14801-970 Araraquara, SP, Brasil \\ ${ }^{5}$ Instituto Federal de São Paulo, Campus Avançado de Matão, 15990-040 Matão, SP, Brasil
}

Manuscript received on January 19, 2012; accepted for publication on February 27, 2013

\begin{abstract}
Casearia sylvestris Swartz (Salicaceae) has been used in traditional medicine and its leaf extracts have been exhibited important pharmacological activities. The species presents morphological, chemical and genetic variation. Two varieties are considered due external morphological differences: $C$. sylvestris var. sylvestris and var. lingua. There are difficulties in definition of these varieties. The objective of this work is to evaluate chemical and morpho-anatomical differences between $C$. sylvestris varieties that can be applied in their distinction for pharmaceutical or botanical purposes. Transverse and paradermic sections of leaves were prepared for morphoanatomical, histochemical and quantitative microscopy (stomatal and palisade index) analyses. Diterpene profiles of the specimens were obtained by HPLC-DAD and TLC. Morpho-anatomical analyses demonstrated significant differences between the varieties only in paradermic sections: var. sylvestris - polygonal epidermic cell walls and hypostomatic; var. lingua - rounded epidermic cell walls and amphistomatic. No differences were observed for stomatal index; palisade index was found 2.8 for var. lingua and 3.9 for var. sylvestris. Chromatographic analyses confirmed previous results demonstrating that diterpene profile in varieties differs, with predominance of these metabolites in var. sylvestris. In conclusion, this work indicates that chromatographic analysis besides morphoanatomical analysis can be applied in distinction of $C$. sylvestris varieties.
\end{abstract}

Key words: Casearia sylvestris, chromatography, diterpenes, morpho-anatomy.

\section{INTRODUCTION}

Casearia sylvestris Swartz (Salicaceae), known as "guaçatonga" or "erva-de-bugre", is a plant species distributed throughout South America that occurs in 22 states of Brazil, especially within the Atlantic

Correspondence to: André Gonzaga dos Santos

E-mail: santosag@fcfar.unesp.br and Amazon forests and the Cerrado biomes (Marquete 2001, Sleumer 1980). The plant has been widely used in traditional medicine for the treatment of snake bites and in wound healing, and also as an antiulcer and topical antiseptic (Hoehne 1939, Lorenzi and Matos 2002). Pharmacological studies on its leaf extracts have demonstrated 
antiulcerogenic, anti-inflammatory, antivenom, and cytotoxic (tumor cell lines) activities. Moreover, no significant toxicological effects of its ethanolic or hydroalcoholic extracts have been observed in vitro or following oral administration in animals (Basile et al. 1990, Borges et al. 2000, Ferreira et al. 2010, Maistro et al. 2004, Santos et al. 2010, Sertiè et al. 2000, Silva et al. 2004). The Brazilian Agency of Medicines (Agência Nacional de Vigilância Sanitária - ANVISA) recognizes the importance of the species that was included in a positive list of medicinal plants for sale in pharmacies (Brasil 2010).

Secondary metabolites isolated/identified from C. sylvestris include monoterpenes and sesquiterpenes (Sousa et al. 2007), nor-isoprenoids (Santos 2008, Wang et al. 2009a), triterpenes, lapachol, cafeic, chlorogenic and vanillic acids, flavonoids (Raslan et al. 2002), neolignans (Wang et al. 2010), ellagic and gallic acids derivatives (Silva et al. 2008a, Silva et al. 2008b). Additionally, phytochemical studies of Casearia species have revealed the presence of typical oxygenated tricyclic $c i s$-clerodane diterpenes in which the tetrahydrofuran ring bears two acyloxy groups at C18 and C19 (Chen and Wiemer 1991, Guittet et al. 1988, Kanokmedhakul et al. 2005, Oberlies et al. 2002, Santos et al.2010). Diterpenes of this group were isolated from $C$. sylvestris: casearins A-X and caseargrewiin F - leaves (Carvalho et al. 1998, Itokawa et al. 1990, Morita et al. 1991, Santos et al. 2010, Wang et al. 2009b); casearvestrins A-C stems and leaves (Oberlies et al. 2002); and roots of rel-19S-acetoxy-18R-butanoyloxy-18,19-epoxy-6Shydroxy-2R-(2-methylbutanoyloxy)-5S,8R,9R,10Scleroda-3,13(16),14-triene (Espíndola et al. 2004). These compounds exhibited some important biological activities as anti-fungal, antiulcer, trypanocidal, and cytotoxicity against human tumor cell lines (Espíndola et al. 2004, Itokawa et al. 1990, Oberlies et al. 2002, Santos 2008, Santos et al. 2010).

Casearia sylvestris was first described by Swartz in Flora Indiae Occidentalis (1797) and Eichler and Martius (1871) included it in Flora
Brasiliensis of Carl Friedrich Philipp von Martius, classified in Bixaceae family. Later it was classified in Flacourtiaceae family (Absy and Scavone 1973, Sleumer 1980). The Angiosperm Phylogeny Group (APG) updated the classification of Angiosperms in 2003 and some genera of Flacourtiaceae (e.g. Casearia Jacq.) were classified as Salicaceae. C. sylvestris Swartz (Crateria Bentahm section) is classified in Samydeae tribe, Salicaceae family and Malpighiales order (Chase et al. 2002, The Angiosperm Phylogeny Group 2003). The macromorphology of the species is described in the work of Torres and Yamamoto (1986), based on descriptions of Eichler and Martius (1871) and Sleumer (1980). The morpho-anatomical characters of the leaves were described by Absy and Scavone (1973) and Alquini and Takemori (2000).

C. sylvestris occurs in different biomes showing great morphological variability: the size, shape, texture and consistency of the leaves, the pubescence of the branches and inflorescences, the number of flowers per inflorescence, the length of peduncle, and its height - shrubs to trees (Marquete 2001, Torres and Yamamoto 1986). Sleumer (1980) considered two varieties to the species due external morphological differences, connected by intermediate forms that are difficult to distinguish: $C$. sylvestris var. sylvestris and $C$. sylvestris var. lingua (Cambess.). Silva et al. (2006) reported differences observed during collection between varieties. In Cerrado biome the specimens were shrubs, with coriaceous lighter green leaves with smaller width and length, corresponding to $C$. sylvestris var. lingua; unlike, specimens of Atlantic Forest were trees with different heights (always higher than 2 $\mathrm{m})$, green dark leaves larger in width and length, corresponding to $C$. sylvestris var. sylvestris. The differences between varieties were summarized by Klein and Sleumer (1984).

Besides the macromorphological differences between the varieties, metabolism variability analyses have suggested a minor expression of diterpenes 
and a greater expression of flavonoids (as rutin) in C. sylvestris var. lingua. Studies of genetic variability also indicated distinct genetic profiles for the varieties (Cavallari 2008, Silva et al. 2006).

Considering the importance of $C$. sylvestris as medicinal plant, the chemical variability observed in previous works, mainly for the bioactive diterpenes and rutin, and the difficulties to distinguish the varieties of $C$. sylvestris by macromorphological analyses in the present article, we report on the evaluation of chemical and morpho-anatomical differences between C. sylvestris varieties that can be applied in their distinction for botanical purposes or pharmaceutical applications.

\section{MATERIALS AND METHODS}

MATERIALS

Leaves of $C$. sylvestris were collected at Araraquara, São Paulo State, in February 16, 2011 (in the morning). C. sylvestris var. lingua (Estação Experimental de Araraquara, Instituto Florestal, São Paulo): AGS38 (S 21.73619, W 48.17987), AGS43 (S 21.73605, W 48.17610), AGS44 (S 21.73600, W 48.17603), AGS45 (S 21.73596, W 48.17605) and AGS51 (S 21.71112, W 48.17339). C. sylvestris var. sylvestris (Universidade Estadual Paulista, UNESP Araraquara; except AGSDER): AGS101 (S 21.81466, W 48.20215), AGS102 (S 21.81466, W 48.20215), AGS103 (S 21.81631, W 4819838), AGS104 (S 21.81430, W 48.20160) and AGSDER (S 21.73596, W 4818850). Voucher specimens of AGS38, AGS43, AGS44, AGS45 AGS51, AGS101 and AGS102 were deposited with the Herbarium "Maria Eneida P. Kaufmann" of Instituto Botânico do Estado de São Paulo. AGS103 e AGS104 are clones (plant cutting) of specimens Cs400 and Cs78 that were identified as C. sylvestris var. sylvestris (Cavallari 2008).

The solvents used for extraction and TLC analyses were analytical grade $\left(\right.$ Synth $^{\circledR}$, Diadema, São Paulo, Brazil) whilst those used in HPLC analyses and solid phase extraction (SPE) were
HPLC/UV grade (J. T. Baker ${ }^{\circledR}$, Xalostoc, Mexico). Water was purified (18.1 M $\Omega . \mathrm{cm})$ with a Milli Q plus system (Millipore ${ }^{\circledR}$, São Paulo, Brazil) immediately prior to use. SPE was performed using as stationary phase LiChroprep RP18 (40$63 \mu \mathrm{m}$; Merck ${ }^{\circledR}$, Darmstadt, Germany). Analytical reversed-phase HPLC-DAD was performed using a Shimadzu ${ }^{\circledR}$ system (Kyoto, Japan) comprising a model Prominence ${ }^{\circledR}$ LC-20AT pump, SIL20A autosampler, DGU-20A5 degasser, CTO20A column oven, SPD-M20A photodiode array detector and CBM-20A communication bus module, fitted with Hypersil Gold ${ }^{\circledR} \mathrm{C} 18$ (Thermo ${ }^{\circledR}$ Scientific, USA) column $(250 \times 4.6 \mathrm{~mm}, 5 \mu \mathrm{m})$, with control and data handling managed by LCsolution ${ }^{\circledR}$ multi-PDA software. TLC was developed in silica gel plate aluminum backed (20 x $20 \mathrm{~cm} ; 200 \mu \mathrm{m})$ from Sorbent ${ }^{\circledR}$ Technologies. The chromatographic standards of clerodane diterpenes (caseargrewiin F, casearin B and X) were purified from leaves extracts of $C$. sylvestris and identified as published (Santos et al. 2010). Optical microscopy was developed in a Carl Zeiss ${ }^{\circledR}$ Primo Star microscope. Reagents used in histochemical analysis were prepared as described in literature (Costa 2001, Ganter and Jollés 19691970, Johansen 1940, Valette et al. 1998).

MORPHO-ANATOMICAL ANALYSES

Anatomical freehand sections (paradermic and transverse) of the middle third of fresh leaves from $C$. sylvestris were obtained with a blade. The sections were clarified with sodium hypochlorite commercial solution and wash with deionized water before stain with different reagents (Delafield hematoxylin, Astra blue, iodine green and toluidine blue) for selection of better cell wall staining and visualization of tissue structures. The anatomical descriptions were realized based on microscope visualization $(40 \mathrm{x})$ of the sections on covered glass sheet and comparison with literature data (Absy and Scavone 1973, Alquini and Takemori 2000). 


\section{HISTOCHEMICAL INVESTIGATIONS}

The identification and localization of secondary metabolites in the leaf transverse sections were realized using the follow reagents: Sudan III (Costa 2001, Johansen 1940) and 2.4-dinitrophenylhydrazine (Ganter and Jollés 1969-1970) for terpenes; ferric chloride (Costa 2001, Johansen 1940) and vanillinhydrochloric acid (Costa 2001, Valette et al. 1998) for phenolic compounds.

\section{QUANTITATIVE MicRoscopy}

Palisade index: the average number of palisade cells beneath each epidermal cell is termed the palisade index. The paradermic sections obtained and clarified as described in Morpho-Anatomical Analyses section were mounted on covered glass sheet. Five groups of four epidermal cells were selected in each section. The palisade cells lying beneath each group were counted, being included in the count wich are more than half-covered by the epidermal cells (Evans 2002, Costa 2001).

Stomatal index: the percentage proportion of the ultimate divisions of the epidermis of a leaf which has been converted into stomata is termed the stomatal index (I):

$$
\mathrm{I}=[(\mathrm{S} \times 100) /(\mathrm{E}+\mathrm{S})] \times 100
$$

Where $\mathrm{S}$ is the number of stomata per unit area and $\mathrm{E}$ is the number of ordinary epidermal cells in the same unit area. The paradermic sections (upper and lower surfaces), that were obtained and clarified as described in Morpho-Anatomical Analyses section, were stained with Astra blue and mounted on covered glass sheet (Evans 2002, Costa 2001).

\section{ChromatogRAPHIC ANALYSES}

The following methods were developed and validated to evaluate the diterpene chromatographic profile of $C$. sylvestris leaf samples in the laboratories of Núcleo de Bioensaios, Biossíntese e Ecofisiologia de Produtos Naturais, Instituto de Química, UNESP, Araraquara-SP (data not published).
Extraction: Dried $\left(40^{\circ} \mathrm{C}, 7\right.$ days) and powdered leaves $(1.0 \mathrm{~g})$ from the specimens of $C$. sylvestris were extracted twice in a test tube with $10 \mathrm{~mL}$ of ethyl acetate: hexane: isopropanol 91:08:01 (v/v) by sonication for $1 \mathrm{~h}$. The liquid extracts were filtered, dried at room temperature and at desiccator with silica gel under reduced pressure.

High Performance Liquid Chromatography: $20.0 \mathrm{mg}$ of dried extracts were dissolved in $1.0 \mathrm{~mL}$ of methanol: water $(98: 02, \mathrm{v} / \mathrm{v})$ and submitted to further clean-up by SPE. Laboratory-prepared SPE columns $(20 \times 7$ mm i.d.), dry packed with ca. $1.5 \mathrm{~g}$ of LicChroprep RP18, were activated with methanol and conditioned with methanol: water $(98: 02, \mathrm{v} / \mathrm{v})$. Following application of samples, columns were eluted with $4.0 \mathrm{~mL}$ of methanol: water $(98: 02, \mathrm{v} / \mathrm{v})$. Each eluated was dried in a desiccator with silica gel under reduced pressure, dissolved in methanol $(1.0 \mathrm{~mL})$, and filtered through PVDF membranes $(0.45 \mu \mathrm{m})$ prior to HPLC analysis. The standards of clerodane diterpenes (1.0 $\mathrm{mg}$ ) were dissolved in methanol HPLC grade (1.0 $\mathrm{mL})$ and filtered through PVDF membranes (0.45 $\mu \mathrm{m})$. Aliquots of $20 \mu \mathrm{L}$ were injected onto Hypersil Gold ${ }^{\circledR}$ C18 column $(250 \times 4.6 \mathrm{~mm}, 5 \mu \mathrm{m})$, which were eluted with a mixture of methanol, acetonitrile and water, initially at 22:44:34 (v/v), changing by linear gradient to 47:53:00 over $42 \mathrm{~min}$, isocratically with 47:53:00 for $5 \mathrm{~min}$, and finally isocratically with 22:44:34 for $10 \mathrm{~min}$ (equilibration). The solvent flow rate was $0.8 \mathrm{~mL} / \mathrm{min}$. Detection was at $200-700 \mathrm{~nm}$ for all samples. Caseargrewiin F, casearin B and X $(1.0 \mathrm{mg} / \mathrm{mL}$; methanol) were used as standards.

Casearin-like diterpenes present two different patterns of conjugated double bond in their lateral chain (C11-C16) - C12(Z or E)/C14 or C13(16)/C14 - and their UV spectra present one band and $\lambda_{\max }=$ 231-238 or 221-228 nm, respectively (Carvalho et al. 2009, Espíndola et al. 2004, Itokawa et al. 1990). Thus, we suggested that peaks with UV spectra with one band and $\lambda_{\max }=221-228$ or $231-238$ $\mathrm{nm}$ were relative to the casearin-like diterpenes. 
Carvalho et al. (2009) analyzed different organs of $C$. sylvestris with similar approach and results from HPLC-DAD analyses were confirmed by ${ }^{1} \mathrm{H}$ NMR and TLC data. Moreover, five casearin-like diterpenes isolated from leaves of $C$. sylvestris were identified in its extract and presented peaks with $t_{R}$ in the range of 10-30 min in the same HPLC conditions (Santos 2008). Additionally, as observed by Carvalho et al. (2009), peaks with a second band in the UV spectra with $\lambda_{\max }$ of c.a. $280 \mathrm{~nm}$, indicate the presence of clerodane diterpenes with a aromatic ester substituent, as reported in the literature (Beutler et al. 2000). Thus, clerodane diterpenes were identified in the extract chromatograms on the basis of UV spectra of the peaks. Additionally, the comparison of retention time $\left(t_{R}\right)$ and UV spectra of peaks from standard and extract chromatograms was realized.

Thin Layer Chromatography: $8.0 \mathrm{mg}$ of dried extracts and $1.0 \mathrm{mg}$ of caseargrewiin $\mathrm{F}$ and casearin $\mathrm{B}$ were dissolved in $1.0 \mathrm{~mL}$ of ethyl acetate. TLC was developed in silica gel plate aluminum backed (20 x $20 \mathrm{~cm} ; 200 \mu \mathrm{m})$ using hexane: ethyl acetate: isopropanol 70:28:02 (v/v) as eluent and sulfuric anisaldehyde as spray reagent.

\section{RESULTS}

The macromorphological differences between the varieties of $C$. sylvestris reported were evident during the collection and the specimens were classified as C. sylvestris var. lingua or C. sylvestris var. sylvestris as described by Sleumer (1980) and Klein and Sleumer (1984).

In the morpho-anatomical study, the best visualization in transverse sections was achieved with dual staining: Delafield hematoxylin followed by green iodine. No significant anatomical differences were observed in transverse sections for the varieties. Morpho-anatomical characters of the leaves were in agreement with literature (Absy and Scavone 1973, Alquini and Takemori 2000). In the midvein region of leaf sections we observed typical cells of xylem, phloem, collenchyma and parenchyma, in addition to fibers associated with vascular bundles (Figure 1a). Both upper and lower epidermises were uniseriate, presenting a lower number of simple nongladular trichomes. The mesophyll is asymmetrical and heterogeneous with two (rarely three) layers of palisade parenchyma and several layers of spongy parenchyma with irregular cells in shape and size. The air spaces (meatus) occur in small proportion in spongy parenchyma (Figure 1b). We also noted the presence of spiral vessels, oil glands, druses and prismatic crystals (calcium oxalate) (Figure 2).

For the paradermic sections, the best stain reagent was Astra blue. In this case we observed significant differences between the varieties. The epidermic cell walls are polygonal in C. sylvestris
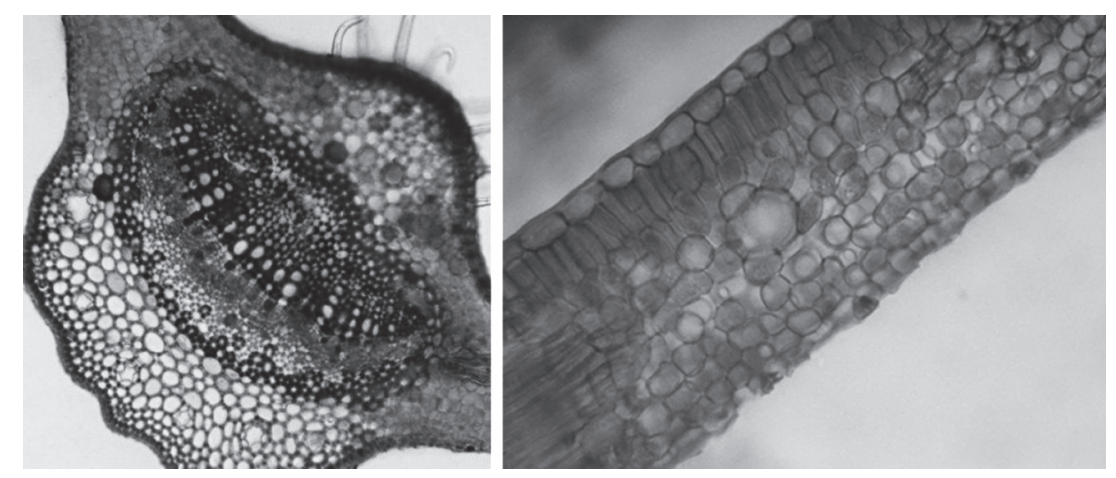

Figure 1 - Tranverse section of the midvein region from the leaf of $C$. sylvestris var. lingua (a) and tranverse section of the region between the midvein and the margin from the leaf of C. sylvestris var. sylvestris (b). 


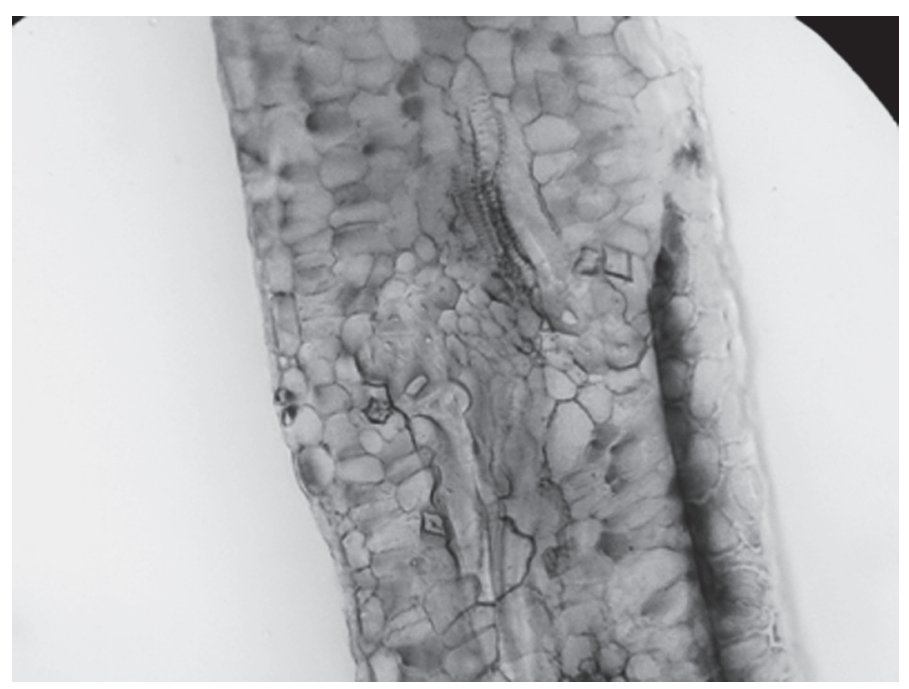

Figure 2 - Transverse section of the region between the midvein and the margin from the leaf of C. sylvestris var. lingua.

var. sylvestris and rounded in C. sylvestris var. lingua (Figure 3). Moreover, C. sylvestris var. sylvestris is hypostomatic and C. sylvestris var. lingua is amphistomatic. The stomata are paracytic in both varieties.

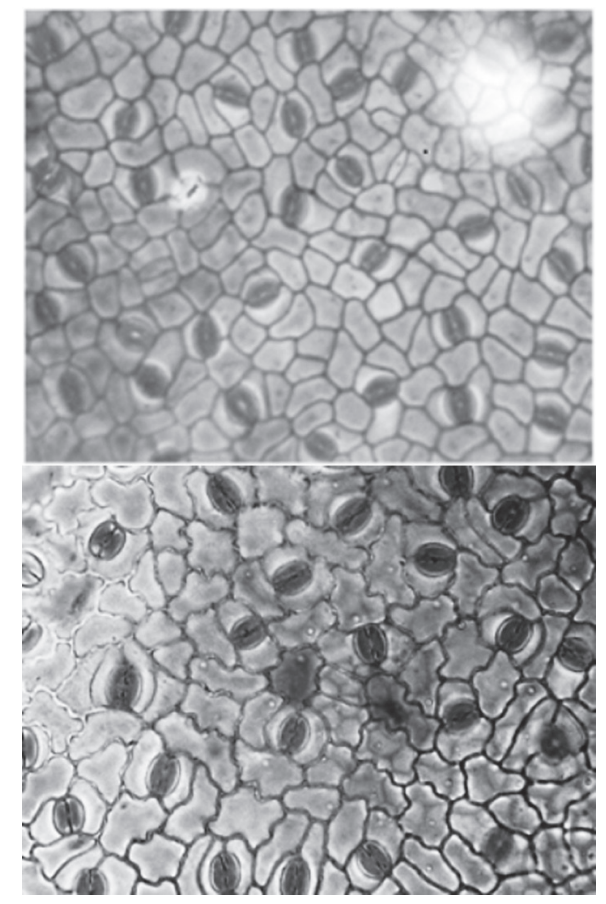

Figure 3 - Paradermic sections (lower epidermis) from the leaf of C. sylvestris var. sylvestris (a) and var. lingua (b).
Histochemical reagents did not differentiate the varieties and the results were positive for both terpenes and phenolics (all reagents tested).

The results of quantitative microscopy are in Tables I and II. The values of stomatal index for specimens of $C$. sylvestris var. sylvestris presented great variation: 11.9 to $20.7 \%$ (standard deviation $=$ 3.4). In the case of $C$. sylvestris var. lingua specimens these values were more homogeneous (standard deviation $=0.2$ ). The mean value of stomatal index for both varieties was similar: 15.9 (var. sylvestris) and $16.4 \%$ (var. lingua). On the other hand, palisade index was found 2.8 for var. lingua and 3.9 for var. sylvestris, demonstrating that this index should be useful in differentiation of C. sylvestris varieties.

TLC analyses provided information about clerodane diterpenes profile of the extracts. Caseargrewiin $F\left(R_{f}=0.23\right)$ was identified by TLC (Figure 4) in the extracts of specimens AGS101, AGS102, AGS103, AGS104 (var. sylvestris), AGS44, AGS45 and AGS51 (var. lingua), while casearin B $\left(\mathrm{R}_{\mathrm{f}}\right.$ $=0.26$ ) was not identified in any extract. Moreover, TLC profiles of var. sylvestris specimens are similar, except for AGSDER. Unlike, specimens of var. lingua presented different TLC profiles, except for AGS44 
TABLE I

Stomatal index for specimens of $C$. sylvestris.

\begin{tabular}{|c|c|c|}
\hline \multirow[b]{2}{*}{ SPECIMEN } & \multicolumn{2}{|c|}{ STOMATAL INDEX (\%) } \\
\hline & $\begin{array}{c}\text { LOWER } \\
\text { EPIDERMIS }\end{array}$ & $\begin{array}{c}\text { UPPER } \\
\text { EPIDERMIS }\end{array}$ \\
\hline \multicolumn{3}{|l|}{ var. sylvestris } \\
\hline AGS103 & 15.6 & $\begin{array}{ll}---- \\
\end{array}$ \\
\hline AGS104 & 13.8 & ----- \\
\hline AGSDER & 11.9 & 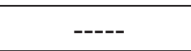 \\
\hline AGS101 & 20.7 & ----- \\
\hline AGS102 & 17.7 & ---- \\
\hline mean $\left(s d^{l}\right)$ & $15.9(3.4)$ & ----- \\
\hline \multicolumn{3}{|l|}{ var. lingua } \\
\hline AGS 38 & 16.3 & 10.3 \\
\hline AGS 43 & 16.5 & 9.5 \\
\hline AGS 44 & 16.1 & 9.7 \\
\hline AGS 45 & 16.7 & 10.1 \\
\hline AGS 51 & 16.4 & 9.2 \\
\hline mean $(s d)$ & $16.4(0.2)$ & $9.8(0.4)$ \\
\hline
\end{tabular}

TABLE II

Palisade index for specimens of $C$. sylvestris.

\begin{tabular}{c|c}
\hline SPECIMEN & PALISADE INDEX \\
\hline var. sylvestris & 3.7 \\
AGS103 & 4.3 \\
AGS104 & 3.8 \\
AGSDER & 3.9 \\
AGS101 & 3.8 \\
AGS102 & $3.9(0.2)$ \\
mean (sd $\left.{ }^{1}\right)$ & \\
var. lingua & 3.1 \\
AGS 38 & 3.2 \\
AGS 43 & 2.5 \\
AGS 44 & 2.6 \\
AGS 45 & 2.6 \\
AGS 51 & $2.8(0.3)$ \\
\hline mean (sd) &
\end{tabular}

${ }^{1}$ standard deviation.

and AGS45. These specimens have TLC profile similar to specimens of var. sylvestris.

Table III presents results of HPLC-DAD analyses for the ten specimens considering number of peaks and area of selected peaks based on

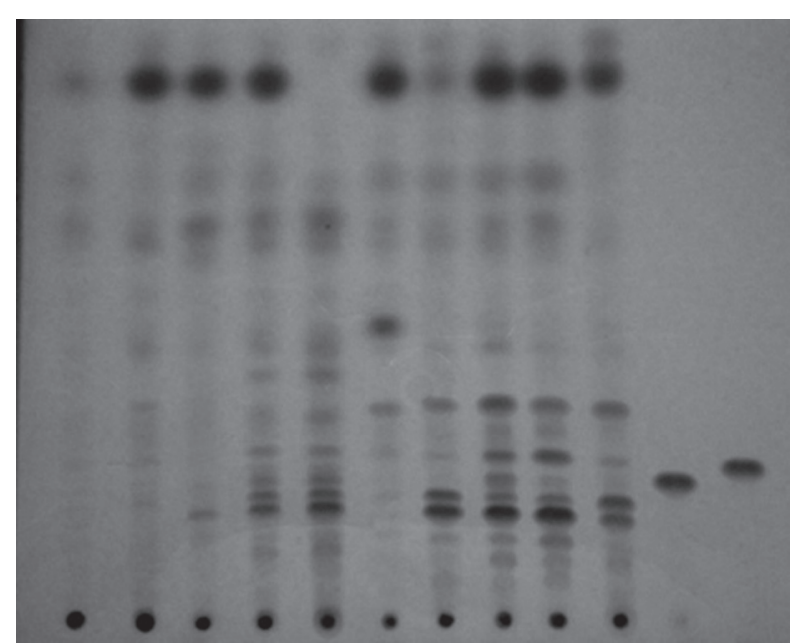

Figure 4 - Thin layer chromatographic profile (silica; hexane: ethyl acetate: isopropanol 70:28:02; sulfuric anisaldehyde) of extracts from leaves of $C$. sylvestris. Samples (from left to right): AGS38, AGS51, AGS43, AGS45, AGS44 (var. lingua); AGSDER, AGS102, AGS101, AGS103, AGS104 (var. sylvestris); caseargrewiin $\mathrm{F}$, casearin $\mathrm{B}$ (clerodane diterpenes).

UV spectra/ $\lambda_{\max }$. Figure 5 shows representative chromatograms of both varieties and the structures of diterpene standards. As observed in the example of Figure 5, there is a greater total area of peaks with $t_{R}<5$ min in the chromatograms of specimens of C. sylvestris var. lingua and AGSDER (var. sylvestris) than in chromatograms of AGS101-104 (var. sylvestris). On the other hand, the total area of peaks with $\lambda_{\max }=221-228$ or $231-238 \mathrm{~nm}$ is greater in chromatograms of AGS101-104 (Table III).

We classified the specimens in three groups on the basis of the observed common main peaks (peaks with larger area), identification of clerodane diterpenes (caseargrewiin $\mathrm{F}$, casearin $\mathrm{B}$ and $\mathrm{X}$ ) and predominance of peaks with UV spectrum with $\lambda_{\max }=$ 221-228 or $231-238 \mathrm{~nm}$. The diterpene standards were identified in the extracts by comparison of their $t_{R}$ and UV spectra. Tables IV-VI present data from chromatograms of the three groups: group 1 - AGS38, AGS44-45 (var. lingua); group 2 - AGS43 and AGS51 (var. lingua); group 3 - AGS101-104 (var. sylvestris). AGSDER demonstrated a chromatographic profile with characteristics of different groups. 
TABLE III

HPLC-DAD analyses data of leaf extracts from different specimens of $C$. sylvestris. The number of peaks and total area of selected peaks based on UV spectra $/ \lambda_{\max }$ are presented.

\begin{tabular}{|c|c|c|c|c|c|c|c|c|}
\hline \multirow{2}{*}{ specimen } & \multicolumn{2}{|c|}{$\lambda_{\max }=221-228 \mathrm{~nm}$} & \multicolumn{2}{|c|}{$\lambda_{\max }=231-238 \mathrm{~nm}$} & \multicolumn{2}{|c|}{$\begin{array}{c}\lambda_{\max }=221-228 \mathrm{~nm} \\
\text { and c.a. } 280 \mathrm{~nm}\end{array}$} & \multicolumn{2}{|c|}{$\begin{array}{c}\lambda_{\max }=231-238 \mathrm{~nm} \\
\text { and c.a. } 280 \mathrm{~nm}\end{array}$} \\
\hline & total area & $\begin{array}{l}\text { n. of } \\
\text { peaks }\end{array}$ & total area & $\begin{array}{l}\text { n. of } \\
\text { peaks }\end{array}$ & total area & $\begin{array}{c}\text { n. of } \\
\text { peaks }\end{array}$ & total area & $\begin{array}{c}\text { n. of } \\
\text { peaks }\end{array}$ \\
\hline \multicolumn{9}{|l|}{ var. sylvestris } \\
\hline AGS101 & $1,487,789$ & 4 & $205,577,366$ & 29 & $10,618,521$ & 6 & $3,406,177$ & 2 \\
\hline AGS102 & $1,094,944$ & 3 & $142,165,961$ & 25 & $2,437,009$ & 3 & $8,897,657$ & 4 \\
\hline AGS103 & $3,204,639$ & 3 & $241,678,210$ & 33 & 355,487 & 1 & 977,877 & 1 \\
\hline AGS104 & $2,070,050$ & 4 & $223,721,237$ & 24 & $5,375,576$ & 5 & $12,867,946$ & 2 \\
\hline AGSDER & $7,808,800$ & 13 & $7,670,449$ & 3 & $2,537,429$ & 5 & -- & -- \\
\hline \multicolumn{9}{|l|}{ var. lingua } \\
\hline AGS38 & $25,490,047$ & 22 & $4,976,442$ & 3 & 989,125 & 2 & -- & -- \\
\hline AGS43 & $2,410,937$ & 6 & $52,521,251$ & 17 & $1,821,007$ & 4 & -- & -- \\
\hline AGS44 & $55,220,208$ & 23 & $8,368,142$ & 2 & $2,633,624$ & 6 & 342,820 & 1 \\
\hline AGS45 & $34,518,773$ & 23 & $31,243,011$ & 2 & $4,585,270$ & 5 & -- & -- \\
\hline AGS51 & 790,020 & 8 & $21,440,354$ & 16 & -- & -- & -- & -- \\
\hline
\end{tabular}

TABLE IV

Data from HPLC-DAD analyses of specimens AGS38, AGS44 and AGS45. Retention time, area and $\lambda_{\max }$ of selected peaks $\left(t_{R}>10 \mathrm{~min}\right.$; area $>10^{6}$ in at least one specimen of the group) are presented.

\begin{tabular}{ccc|ccc|ccc}
\hline & AGS38 & \multicolumn{3}{c|}{ AGS44 } & \multicolumn{3}{c}{ AGS45 } \\
\hline $\mathrm{t}_{\mathrm{R}}(\mathrm{min})$ & area & $\lambda_{\max }{ }^{1}(\mathrm{~nm})$ & $\mathrm{t}_{\mathrm{R}}(\mathrm{min})$ & area & $\lambda_{\max }(\mathrm{nm})$ & $\mathrm{t}_{\mathrm{R}}(\min )$ & area & $\lambda_{\max }(\mathrm{nm})$ \\
\hline 10.1 & $214,038^{3}$ & 220 & 10.1 & $3,544,160$ & 223 & 10.0 & $4,007,308$ & 223 \\
\hline 12.0 & 230,733 & 220 & 12.1 & $2,779,635$ & 223 & 12.0 & $3,827,383$ & 223 \\
\hline 13.9 & $1,441,518$ & 223 & 13.9 & $1,772,768$ & 223 & 13.8 & $2,932,737$ & 223 \\
\hline 15.0 & $6,096,411$ & 239 & 15.0 & $15,390,898$ & 238 & 14.9 & $16,979,443$ & 238 \\
\hline 15.6 & $2,749,524$ & 223 & 15.6 & $6,391,880$ & 223 & 15.5 & $7,712,235$ & 222 \\
\hline $\mathbf{1 6 . 8}$ & $4,072,823$ & 237 & $\mathbf{1 6 . 9}$ & $17,521,082$ & 237 & $\mathbf{1 6 . 7}$ & $14,263,568$ & 237 \\
\hline 18.2 & $2,416,173$ & 223 & 18.2 & $1,976,262$ & 223 & 18.0 & $3,328,239$ & 223 \\
\hline 19.7 & $3,297,201$ & 223 & 19.7 & 655,312 & 223 & 19.6 & $1,541,503$ & 223 \\
\hline--- & --- & --- & --- & --- & --- & 19.9 & $1,945,180$ & 223 \\
\hline 22.7 & 881,097 & 223 & 22.7 & 682,384 & 223 & 22.5 & $1,182,339$ & 223 \\
\hline 27.6 & $2,022,085$ & 223 & 27.6 & $6,344,883$ & 221 & 27.4 & $7,792,553$ & 220 \\
\hline 31.6 & $1,672,354$ & 223 & 31.7 & 208,153 & 223 & 31.5 & 340,354 & 223 \\
\hline 32.5 & $2,418,817$ & 223 & 32.7 & $2,024,131$ & 223 & 32.5 & $2,625,140$ & 223 \\
\hline--- & --- & --- & --- & --- & --- & 35.0 & $1,641,322$ & --- \\
\hline 37.1 & $1,007,356$ & 223 & 37.1 & 44,921 & 220 & 36.9 & 245,582 & --- \\
\hline 37.9 & $1,036,496$ & 223 & 37.8 & 14,956 & 220 & 37.6 & 55,241 & --- \\
\hline
\end{tabular}

${ }^{1}$ all spectra presented one band.

${ }^{2}$ peak identified as caseargrewiin $\mathrm{F}\left(\mathrm{t}_{\mathrm{R}}=16.9 \min ; \lambda_{\max }=235 \mathrm{~nm}\right)$.

${ }^{3}$ values in italic indicates that peak area $<10^{6}$ for this specimen. 
TABLE V

Data from HPLC-DAD analyses of specimens AGS43 and AGS51. Retention time, area and $\lambda_{\max }$ of selected peaks $\left(t_{R}>10 \mathrm{~min}\right.$; area $>10^{6}$ in at least one specimen of the group) are presented.

\begin{tabular}{ccc|ccc}
\hline \multicolumn{3}{c}{ AGS43 } & \multicolumn{3}{c}{ AGS51 } \\
\hline $\mathrm{t}_{\mathrm{R}}(\mathrm{min})$ & area & $\lambda_{\max }{ }^{1}(\mathrm{~nm})$ & $\mathrm{t}_{\mathrm{R}}(\min )$ & area & $\lambda_{\max }(\mathrm{nm})$ \\
\hline 10.7 & $2,444,373$ & 234 & 10.7 & 551,446 & 231 \\
\hline 12.8 & $2,667,364$ & 234 & --- & --- & --- \\
\hline 13.4 & $2,884,543$ & 234 & --- & --- & --- \\
\hline 14.5 & $1,364,805$ & 233 & 14.3 & 197,898 & 231 \\
\hline 15.0 & $6,532,573$ & 238 & --- & --- & --- \\
\hline 15.9 & $14,370,840$ & 234 & 16.2 & $1,322,891$ & 234 \\
\hline 16.4 & $2,578,648$ & 234 & --- & --- & --- \\
\hline $\mathbf{1 6 . 8}$ & $2,388,160$ & 236 & $\mathbf{1 6 . 6}$ & $2,111,535$ & 237 \\
\hline 18.0 & $1,430,820$ & 231 & 17.7 & 302,861 & 233 \\
\hline $\mathbf{1 9 . 1}$ & $2,020,369$ & 234 & $\mathbf{1 8 . 8}$ & $2,741,439$ & 234 \\
\hline--- & --- & --- & 20.1 & $6,083,237$ & 234 \\
\hline 20.7 & $6,040,123$ & 234 & --- & --- & --- \\
\hline $\mathbf{2 1 . 6}$ & $1,475,264$ & 233 & $\mathbf{2 1 . 3}$ & 317,727 & 232 \\
\hline 23.3 & $1,245,694$ & 231 & 23.0 & $1,759,548$ & 234 \\
\hline 28.2 & $2,392,835$ & 234 & --- & --- & --- \\
\hline 29.8 & $1,090,286$ & 227 & 29.6 & 103,058 & 227 \\
\hline--- & --- & --- & 31.9 & $1,228,921$ & 234 \\
\hline 33.1 & $5,187,343$ & 230 & 32.8 & $1,505,320$ & 234 \\
\hline 35.1 & $1,660,173$ & 259 & 34.9 & 184,321 & 258 \\
\hline 35.9 & $1,254,948$ & 233 & 35.7 & 335,305 & 230 \\
\hline & & & & &
\end{tabular}

${ }^{1}$ all spectra presented one band.

${ }^{2}$ peaks identified as caseargrewiin $\mathrm{F}\left(\mathrm{t}_{\mathrm{R}}=16.9 \mathrm{~min} ; \lambda_{\max }=235 \mathrm{~nm}\right)$, casearin $\mathrm{B}\left(\mathrm{t}_{\mathrm{R}}=19.0\right.$ min; $\left.\lambda_{\max }=233 \mathrm{~nm}\right)$ or casearin $\mathrm{X}\left(\mathrm{t}_{\mathrm{R}}=21.4 \mathrm{~min} ; \lambda_{\max }=234 \mathrm{~nm}\right)$.

${ }^{3}$ values in italic indicates that peak area $<10^{6}$ for this specimen.

\section{TABLE VI}

Data from HPLC analyses of specimens AGS101-104. Retention time, area and $\lambda_{\max }$ of selected peaks $\left(t_{R}>10 \mathrm{~min}\right.$; area $>10^{7}$ in at least one specimen of the group) are presented.

\begin{tabular}{|c|c|c|c|c|c|c|c|c|c|c|c|}
\hline \multicolumn{3}{|c|}{ AGS101 } & \multicolumn{3}{|c|}{ AGS102 } & \multicolumn{3}{|c|}{ AGS103 } & \multicolumn{3}{|c|}{ AGS104 } \\
\hline $\begin{array}{c}\mathrm{t}_{\mathrm{R}} \\
(\mathrm{min})\end{array}$ & area & $\begin{array}{l}\lambda_{\max }{ }^{1} \\
(\mathrm{~nm})\end{array}$ & $\begin{array}{c}t_{\mathrm{R}} \\
(\mathrm{min})\end{array}$ & area & $\begin{array}{c}\lambda_{\max } \\
(\mathrm{nm})\end{array}$ & $\begin{array}{c}\mathrm{t}_{\mathrm{R}} \\
(\mathrm{min})\end{array}$ & area & $\begin{array}{l}\lambda_{\max } \\
(\mathrm{nm})\end{array}$ & $\begin{array}{c}t_{\mathrm{R}} \\
(\mathrm{min})\end{array}$ & area & $\begin{array}{c}\lambda_{\max } \\
(\mathrm{nm})\end{array}$ \\
\hline 11.5 & $51,753,295$ & 232 & 11.5 & $41,903,478$ & 234 & 11.4 & $63,905,455$ & 232 & 11.5 & $35,911,329$ & 232 \\
\hline 14.9 & $2,274,634$ & 237 & 15.1 & $4,923,216$ & 235 & 14.9 & $12,408,073$ & 238 & 15.0 & $10,271,162$ & 235 \\
\hline 16.3 & $8,262,055$ & 234 & 16.3 & $27,280,273$ & 231 & 16.2 & $19,190,603$ & 233 & 16.1 & $51,263,748$ & 232 \\
\hline $16.7^{2}$ & $3,172,351$ & 235 & $16.7^{2}$ & $2,946,438$ & 237 & $16.6^{2}$ & $11,387,481$ & 237 & $16.6^{2}$ & $6,483,562$ & 237 \\
\hline $18.9^{2}$ & $16,510,122$ & 233 & $18.9^{2}$ & $4,863,225$ & 234 & $18.8^{2}$ & $31,961,624$ & 232 & $18.8^{2}$ & $14,334,030$ & 233 \\
\hline 20.2 & $39,245,812$ & 232 & 20.2 & $20,544,230$ & 233 & 20.2 & $30,553,286$ & 232 & 20.1 & $40,426,106$ & 232 \\
\hline $21.5^{2}$ & 602,260 & 234 & $21.6^{2}$ & $2,524,503$ & 234 & $21.4^{2}$ & $3,562,338$ & 235 & $21.5^{2}$ & $2,283,234$ & 234 \\
\hline 23.1 & $15,510,748$ & 234 & 23.1 & $5,300,509$ & 235 & 23.1 & $11,112,349$ & 234 & 23.0 & $11,399,559$ & 234 \\
\hline 32.0 & $14,119,935$ & 234 & 31.9 & $1,418,784$ & 235 & 31.9 & $7,955,250$ & 234 & 31.9 & $1,592,905$ & 234 \\
\hline 33.0 & $10,990,895$ & 234 & 32.8 & $5,918,022$ & 234 & 32.8 & $18,209,028$ & 232 & 32.8 & $2,665,132$ & 234 \\
\hline
\end{tabular}

${ }^{1}$ all spectra presented one band.

${ }^{2}$ peaks identified as caseargrewiin $F\left(t_{R}=16.9 \min ; \lambda_{\max }=235 \mathrm{~nm}\right)$, casearin $B\left(t_{R}=19.0\right.$ min; $\left.\lambda_{\max }=233 \mathrm{~nm}\right)$ or casearin $X$ $\left(t_{\mathrm{R}}=21.4 \mathrm{~min} ; \lambda_{\max }=234 \mathrm{~nm}\right)$.

${ }^{3}$ peak area values in italic highlights that peak area $<10^{7}$ for this specimen. 

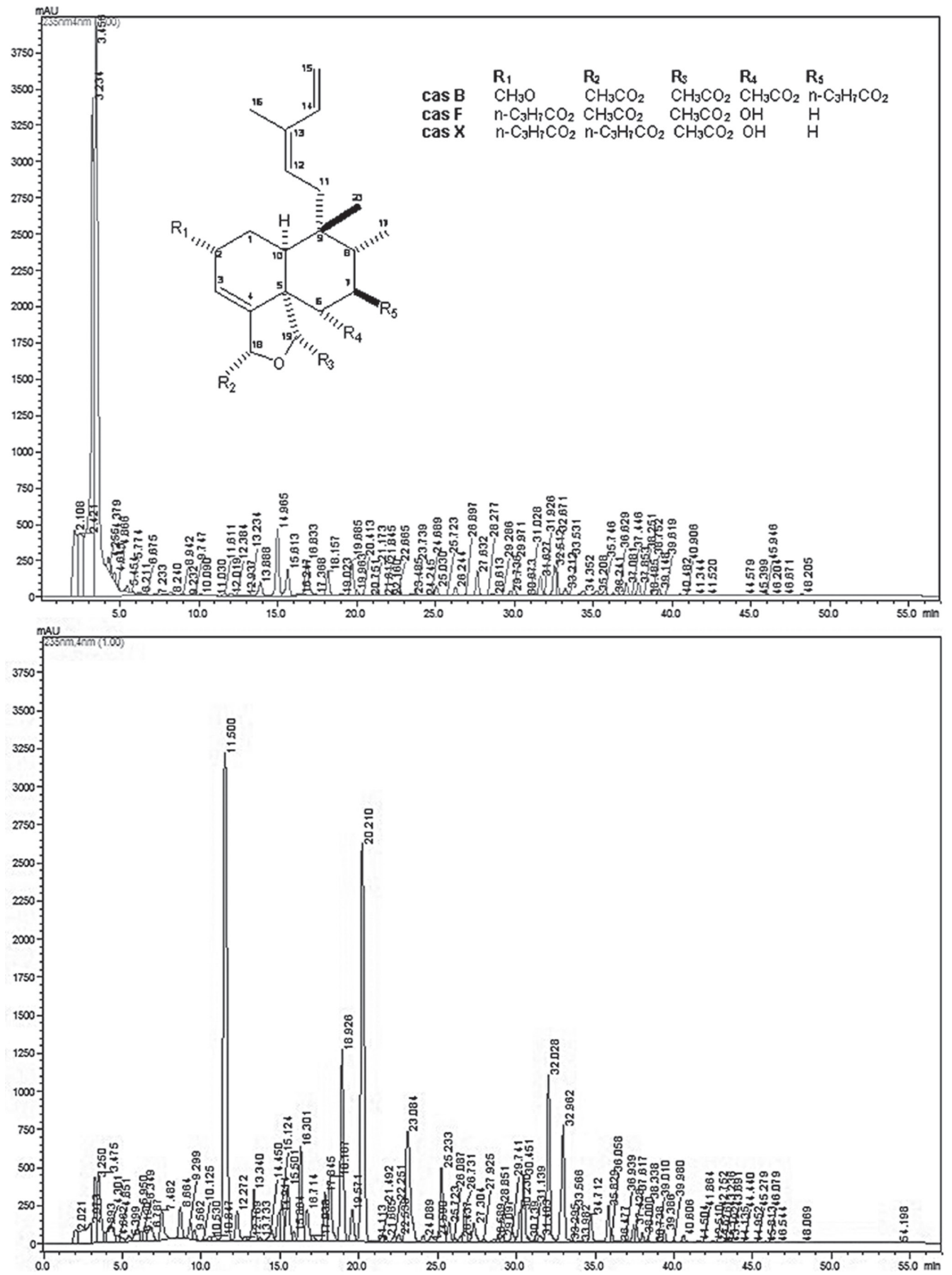

Figure 5 - Representative high performance liquid chromatography (C18; methanol: acetonitrile: water gradient; $235 \mathrm{~nm})$ profile of extracts from leaves of C. sylvestris - specimens AGS38 var. lingua (top) and AGS101 var. sylvestris (bottom). Structures of diterpenes standards are presented: caseargrewiin F (cas F), casearins B and X (cas B and cas X). 


\section{DISCUSSION}

The morpho-anatomical comparison between the varieties revealed differences only in the paradermic sections. The shape of epidermic cell walls (polygonal in var. sylvestris and rounded in var. lingua) and stomata distribution (var. sylvestris is hypostomatic and var. lingua is amphistomatic) are characteristics that can be applied in the differentiation of the varieties as well as the palisade index. According Costa (2001) the palisade index is less affected by environmental factors than stomatal index. These results are interesting for the pharmaceutical quality control application because the analysis of the powdered drug will lead to the identification of the varieties. Obviously, the assays will be applied to more representative number of specimens from different environments or regions to be validated.

Data from HPLC-DAD analyses $\left(t_{R}\right.$ and UV spectrum) allowed to classify the specimens in three groups. In the first group - AGS38, AGS44 and AGS45 (var. lingua) - we found the following common characteristics: identification only of caseargrewiin $\mathrm{F}$, predominance of peaks with $\lambda_{\text {max }}=221-228 \mathrm{~nm}$ (22-23 peaks and total peak area of 22-55 $\times 10^{6}$ ), and seven common main peaks with area $>10^{6}$ (Tables III and IV). In TLC analyses caseargrewiin $\mathrm{F}$ was not identified in AGS38 probably due its minor concentration as demonstrated by HPLC analysis (small peak area).

In the second group - AGS43 and AGS51 (var. lingua) - caseargrewiin $\mathrm{F}$, casearins $\mathrm{B}$ and $\mathrm{X}$ were identified. In the TLC analyses, diterpenes were not identified as discussed above. The peaks with $\lambda_{\max }=231-238 \mathrm{~nm}$ have greater area (16-17 peaks and total peak area of $\left.21-53 \times 10^{6}\right)$ than peaks with $\lambda_{\max }=221-228 \mathrm{~nm}$ (6-8 peaks and total peak area of 0.8-2.4 x $10^{6}$ ) (Table III). Finally, there are five common main peaks with area $>106$ (Table V) in their chromatograms.

The third group includes AGS101-104 (var. sylvestris). In this group the peaks with $\lambda_{\max }=231$ -
$238 \mathrm{~nm}$ predominate notably in number of peaks (24-33) and total peak area (142-242 x 106) in comparison with all specimens of var. lingua (Table III). The three diterpenes were identified in these specimens and they have six common main peaks with area $>4 \times 10^{6}$ (Table VI). In the TLC analysis, casearin $\mathrm{B}$ was not identified as discussed above.

The specimen AGSDER presented characteristics of different groups. Its chromatogram demonstrated that peaks with $\lambda_{\max }=221-228 \mathrm{~nm}$ predominate in number (13) but no differences were observed for peak total area $\left(8 \times 10^{6}\right)$ considering the two ranges of $\lambda_{\max }$. Casearin B and caseargrewiin $\mathrm{F}$ were identified in HPLC-DAD analysis.

The results obtained suggest the predominance of clerodane diterpenes, especially with $\lambda_{\max }=231$ $238 \mathrm{~nm}$, in C. sylvestris var. sylvestris. Moreover, there is a greater total area of peaks with $t_{R}<5$ min in the chromatograms of specimens of $C$. sylvestris var. lingua and AGSDER (var. sylvestris) than in chromatograms of AGS101-104 (var. sylvestris) indicating greater concentration of polar compounds (e.g. phenolics) as demonstrated in previous work (Cavallari 2008, Silva et al. 2006). AGSDER was in an urban area subjected to pollutants and it may be correlated with its different chemical pattern.

As morpho-anatomical analyses, the chemical analyses by HPLC-DAD have to be applied to greater number of specimens from different environments or regions to give more conclusive results.

In conclusion, this work indicates that chemical analyses, mainly HPLC-DAD, besides morpho-anatomical analyses of paradermic sections and palisade index can be applied in distinction of C. sylvestris varieties for botanical or pharmaceutical purposes.

\section{ACKNOWLEDGMENTS}

The authors are grateful to the Conselho Nacional de Desenvolvimento Científico e Tecnológico (CNPq), Coordenação de Aperfeiçoamento de Pessoal de Nível Superior (CAPES), Fundação para o Desenvolvimento da UNESP (FUNDUNESP), 
Fundação de Amparo à Pesquisa do Estado de São Paulo (FAPESP), and Instituto Florestal da Secretaria do Meio Ambiente do Estado de São Paulo for support of the project.

\section{RESUMO}

Casearia sylvestris Swartz (Salicaceae) é uma planta utilizada na medicina tradicional, cujos extratos de folhas demonstraram importantes ações farmacológicas. A espécie apresenta variação morfológica, genética e química. Duas variedades são consideradas devido a diferenças morfológicas: C. sylvestris var. sylvestris e var. lingua. Há dificuldades na definição destas variedades. O objetivo deste trabalho é avaliar diferenças morfo-anatômicas e químicas entre as variedades de C. sylvestris que permitam sua diferenciação com aplicação farmacêutica ou botânica. Seções transversais e paradérmicas de folhas foram preparadas para análises morfo-anatômicas, histoquímicas e microscopia quantitativa (indices de estômatos e paliçada). Análises cromatográficas (CLAE-DAD e CCD) foram realizadas para obter o perfil de diterpenos clerodânicos. Os resultados das análises morfo-anatômicas demonstraram diferenças significativas entre as variedades somente em cortes paradérmicos: var. sylvestris - paredes celulares epidérmicas poligonais e hipoestomática, var. lingua - paredes celulares epidérmicas arredondadas e anfiestomática. Os índices de estômatos não revelaram diferenças; os valores dos índices de paliçada foram de 2,8 para var. lingua e 3,9 para var. sylvestris. As análises cromatográficas confirmaram resultados prévios, demonstrando predomínio de diterpenos na var. sylvestris. Este trabalho sugere que análises cromatográficas e morfoanatômicas podem ser ferramentas aplicáveis na distinção das variedades da espécie.

Palavras-chave: Casearia sylvestris, cromatografia, diterpenos, morfo-anatomia.

\section{REFERENCES}

ABSY ML AND SCAVONE O. 1973. Sobre a morfologia e anatomia da Casearia sylvestris Swartz. Bol Zool Biol Mar 30: 641-676.

ALQUINI Y AND TAKEMORI NK. 2000. Organização estrutural de espécies vegetais de interesse farmacológico. Curitiba: Herbarium Laboratório Botânico, 80 p.
Basile AC, Sertie JAA, PAnNizza S, Oshiro TT AND AzZolini CA. 1990. Pharmacological assay of Casearia sylvestris. I: Preventive anti-ulcer activity and toxicity of the leaf crude extract. J Ethnopharmacol 30: 185-197.

Beutler JA, McCall KL, Herbert K, Herald DL, Pettit GR, JOHNSON T, SHOEMAKER RH AND BOYD MR. 2000. Novel cytotoxic diterpenes from Casearia arborea. J Nat Prod 63: 657-661.

BORgES MH, SOARES AM, RODRIGUES VM, ANDRIÃOESCARSO SH, DINIZ H, HAMAGUCHI A, QUINTERO A, LIZANO S, GUTIÉRREZ JM, GIGLIO JR AND HOMSI-BRANDEBURGO MI. 2000. Effects of aqueous extract of Casearia sylvestris (Flacourtiaceae) on actions of snake and bee venoms and on activity of phospholipases $\mathrm{A}_{2}$. Comp Biochem Physiol Part B: Biochem Mol Biol 127: 21-30.

BRASIL. 2010. Agência Nacional de Vigilância Sanitária. Resolução n. 10, de 9 de março de 2010. Dispõe sobre a notificação de drogas vegetais junto à Agência Nacional de Vigilância Sanitária (ANVISA) e dá outras providências. Diário Oficial da União, Brasília, 11 mar.

Carvalho ES, SAntos AG AND Cavalheiro AJ. 2009. Identificação de diterpenos clerodânicos em diferentes órgãos de Casearia sylvestris Swartz. Rev Ciênc Farm Básica Apl 30: 277-284.

CARVALHO PRF, FURLAN M, Young MCM, KingSTON DGI AND BOLZANI V DA S. 1998. Acetylated DNA-damage clerodane diterpenes from Casearia sylvestris. Phytochemistry 49: $1659-1662$

CAVALLARI MM. 2008. Variabilidade genética e química entre e dentro de populações de Casearia sylvestris Sw. (Salicaceae) no Estado de São Paulo. Tese (Doutorado em Ciências Biológicas) - Instituto de Biociências, Universidade Estadual Paulista, Botucatu, 115 p. (Unpublished).

Chase MW, ZMartzty S, Lledó MD, Wurdack KJ, SWENSEN SM AND FAY MF. 2002. When in doubt, put it in Flacourtiaceae: a molecular phylogenetic analysis based on plastid $r b c L$ DNA sequences. Kew Bull 57: 141-181.

CHEN TB AND WIEMER DF. 1991. Corymbotins A-I: highly oxidized kolovane derivatives from Casearia corymbosa. J Nat Prod 54: 1612-1618.

CostA AF. 2001. Farmacognosia: farmacognosia experimental, $3^{\text {rd }}$ ed., v.3. Lisboa: Fundação Calouste Gulbekian, 999 p.

EICHLER AG AND MARTIUS CFP. 1871. Bixaceae. Flora Brasiliensis 1: 421-488.

Espíndola LS, VASCONCELOS JUNIOR JR, DE MESQUITA ML, MARQuie P, DE PAUla JE, Mambu L and SANTANA JM. 2004. Trypanocidal activity of a new diterpene from Casearia sylvestris var. lingua. Planta Med 70: 1093-1095.

Evans WC. 2002. Trease and Evans Pharmacognosy, $15^{\text {th }}$ ed., London: WB Saunders, 585 p.

FERreira PMP, SANTOS AG, Tininis AG, Costa PM, CAVAlHeiro AJ, Bolzani V Da S, Moraes MO, CostaLotufo LV, Montenegro RC And Pessoa C. 2010. Casearin $\mathrm{X}$ exhibits cytotoxic effects in leukemia cells triggered by apoptosis. Chem-Biol Interact 188: 497-504.

GANTER P AND JOLLES G. 1969-1970. Histochimie normale et pathologique, v. 2. Paris, Villars: Gauthier, 1904 p. 
Guittet E, Stoven V, LALlEMAnd J, RAmiandrasoA F AND KUNESCH G. 1988. Pitumbin, a novel kolavene acylal from Casearia pitumba Pleumer. Tetrahedron 44: 2893-2901.

HoEHne FC. 1939. Plantas e substâncias vegetais tóxicas e medicinais. São Paulo: Graphicars, 355 p.

ITOKaWA H, TOtSUKA N, Morita H, TAKEya K, IITAKA Y, SCHENKEL EP AND MOTIDOME M. 1990. Antitumor principles from Casearia sylvestris Sw. (Flacourtiaceae), structure elucidation of new clerodane diterpenes by 2-D NMR spectroscopy. Chem Pharm Bull 38: 3384-3388.

JOHANSEN DA. 1940. Plant Microtechnique. New York: McGraw-Hill, 523 p.

KANOKMEDHAKUL S, KANOKMEDHAKUL K, KANARSA T AND BUAYAIRAKSA M. 2005. New bioactive clerodane diterpenoids from the bark of Casearia grewiifolia. J Nat Prod 68: 183-188.

KLEIN RMAND SLEUMER HO. 1984. Flora ilustrada catarinense: flacourtiáceas. Itajaí: FLAC, 96 p.

LORENZI H AND MATOS FJA. 2002. Plantas medicinais no Brasil nativas e exóticas. Nova Odessa: Instituto Plantarum, 512 p.

Maistro EL, Carvalho JC AND Mantovani MS. 2004. Evaluation of the genotoxic potential of the Casearia sylvestris extract on HTC and V79 cells by the comet assay. Toxicol In Vitro 18: 337-342.

MARQUETE R. 2001. Reserva ecológica do IBGE (BrasíliaDF): Flacourtiaceae. Rodriguésia 52: 5-16.

Morita H, NAKAYAMA M, KoJIMA H, TAKEya K, ITOKaWA H, SCHENKEL EP AND MOTIDOME M. 1991. Structures and cytotoxic activity relationship of casearins, new clerodane diterpenes from Casearia sylvestris Sw. Chem Pharm Bull 39: 693-697.

Oberlies NH, Burgess JP, NAVArro HA, Pinos RE, FAIRCHILD CR, PETERSON RW, SOEJARTO DD, FARNSWORTH NR, KINGHORN AD, WANI MC AND WALL ME. 2002. Novel bioactive clerodane diterpenoids from the leaves and twigs of Casearia sylvestris. J Nat Prod 65: 95-99.

RASlan DS, JAMAL CM, DUARTE DS, Borges MH AND DE LIMA ME. 2002. Anti-PLA2 action test of Casearia sylvestris Sw. Boll Chim Farmac 141: 457-460.

SANTOS AG. 2008. Identificação dos princípios ativos antiulcerogênicos das folhas de Casearia sylvestris: contribuição para o desenvolvimento de um fitoterápico. Tese (Doutorado em Química) - Instituto de Química, Universidade Estadual Paulista, Araraquara, $361 \mathrm{p}$. (Unpublished).

SANtos AG, Ferreira PMP, VieIra JÚNIOR GM, PEREZ CC, Tininis AG, Silva GH, Bolzani VS, Costa-Lotufo LV, Pessoa C Do Ó AND CAVAlHeIRo AJ. 2010. Casearin X, its degradation product and other clerodane diterpenes from leaves of Casearia sylvestris: evaluation of cytotoxicity against normal and tumor human cells. Chem Biodiversity 7: 205-215.
SERTiè JAA, CARVAlHo JCT AND PANIZZA S. 2000. Antiulcer activity of the crude extract from the leaves of Casearia sylvestris. Pharmaceutical Biology 38: 112-119.

Silva FB, AlmeIdA JM AND SousA SMG. 2004. Natural medicaments in endodontics - a comparative study of the anti-inflammatory action. Braz Oral Res 18: 174-179.

Silva MAS, Ming LC, PEREIRA MAS, BERTONI BW, BATISTINI AP AND PEREIRA PS. 2006. Phytochemical and genetic variability of Casearia sylvestris Sw. From São Paulo State Atlantic Forest and Cerrado populations. Rev Bras P1 Med 8: 159-166.

SILVA SL, CALGarotTo AK, ChaAR JS AND MARANGONI S. 2008a. Isolation and characterization of ellagic acid derivatives isolated from Casearia sylvestris $\mathrm{Sw}$ aqueous extract with anti-PLA2 activity. Toxicon 52: 655-666.

Silva SL, ChaAR JS, DAMICO DC, FIGUEIREDO PMS AND YANO T. 2008b. Antimicrobial activity of ethanol extract from leaves of Casearia sylvestris. Pharmaceutical Biology 46: 347-351.

SLEUMER HO. 1980. Flacourtiaceae: flora neotropica; monograph number 22. New York: The New York Botanic Garden, 499 p.

Sousa FG, SCHNEIDER FZ, MENDEs CE, Moura NF, DENARdin RBN, MATUO R AND MANTOVANI MS. 2007. Clastogenic and anticlastogenic effect of the essential oil from Casearia sylvestris Swart. J Essent Oil Res 19: 376-378.

The Angiosperm Phylogeny Group. 2003. An update of the Angiosperm Phylogeny Group classification for the orders and families of flowering plants: APG II. Bot J Linnean Soc 141: 399-436.

ToRRES RB AND YAMAMOTO K. 1986. Taxonomia das espécies de Casearia Jacq. (Flacourtiaceae) do estado de São Paulo. Revta Bras Bot 9: 239-258.

VAlette C, ANDARy C, Geiger JP. SARAh JL AND Nicole M. 1998. Histochemical and cytochemical investigations of phenols in roots of banana infected by the burrowing nematode Radopholus similes. Phytopathology 88: 1141-1148.

WANG W, ALI Z, Li XC AND KHAN IA. 2010. Neolignans from the Leaves of Casearia sylvestris Swartz. Helv Chim Acta 93: 139-146.

Wang W, Li XC, Ali Z And Khan IA. 2009a. Two new $\mathrm{C}_{13}$ nor-isoprenoids from the leaves of Casearia sylvestris. Chem Pharm Bull 57: 636-638.

Wang W, Zhao J, Wang YH, Smillie TA, Li XC AND Khan IA. 2009b. Diterpenoids from Casearia sylvestris. Planta Med 75: 1476-1481. 